\title{
Intensi Berwirausaha Mahasiswa Berdasarkan Ciri Anggadiredja dan Djajamihardja
}

\author{
Siti Reuni Inayati ${ }^{*}$, Lalu Rizal Ihwandi ${ }^{2}$
}

1,2Universitas Gunung Rinjani, Lombok Timur-Indonesia

A R T I C L E IN F O

Article history:

Received October, 82021

Received in revised form

November, 162021

Accepted November, 20

2021

Available online December, 252021

Kata Kunci:
Anggadiredja,
djajamihardja, intensi,
wirausaha.
Keywords:
Anggadiredja,
djajamihardja entrepreneur,
intention.

\section{A B S T R A K}

Penelitian ini bertujuan untuk Mengetahui Seberapa Tinggi Intensi berwirausaha Mahasiswa Universitas Gunung Rinjani berdasarkan ciri Anggadiredja dan Djajamihardja. Tipe riset ini adalah riset kuantitatif dengan teknik analisis statistik deskriptif. Pengumpulan data menggunakan angket dengan 150 orang mahasiswa sebagai responden. Untuk mengetahui tinggi rendahnya nilai intensi berwirausaha pada mahasiswa peneliti menggunakan kategorisasi yang dibuat berdasarkan rerata hipotetik. Dari hasil kuisioner 150 responden, didapatkan rerata nilai untuk 12 ciri wirausaha menurut Anggadiredja dan Djajamihardja, pertama yaitu Memiliki Emosi untuk Membayangkan Kesuksesan atau Takut akan Kegagalan sebesar 25.87, kedua Berani Menanggung Risiko reratanya yaitu 25.59, ketiga Gigih dan Bekerja Keras nilai rata-ratanya 25.52, keempat Semangat dan Gesit (Mobile) nilai rata-rata diperoleh sebesar 25.37, kelima Membutuhkan Umpan Balik nilai rata-ratanya 25.37, keenam Bertanggungjawab Secara Pribadi atas Perbuatan-perbuatan dan Keputusannya nilai rerata sebesar 26.49, ciri Percaya pada Dirinya Sendiri diperoleh rerata 25.54, kedelapan Mempunyai Pengetahuan Luas diperoleh rerata 25.22, kesembilan Kemampuan Untuk Menghimbau nilai rata-ratanya 24.47, kesepuluh Kecakapan Memimpin nilai rata-ratanya 25.03, kesebelas Pembaharu (Inovator) nilai reratanya 25.54 dan kedua belas Memburu Keberhasilan nilai reratanya sebesar 25.97. Maka dapat ditarik kesimpulan bahwa intensi berwirausaha masing-masing responden berada pada level sedang karena berada pada rentang nilai antara 19-28.5.

\section{A B S T RA C T}

This study aims to determine how high the entrepreneurial intention of Gunung Rinjani University students is based on the characteristics of Anggadiredja and Djajamihardja. This type of research is quantitative research with descriptive statistical analysis techniques. Collecting data using a questionnaire with 150 students as respondents. To find out the high and low value of entrepreneurship intention in the students, the researcher used a categorization based on a hypothetical mean. From the results of a questionnaire of 150 respondents, the average score for 12 entrepreneurial traits according to Anggadiredja and Djajamihardja, first is Having Emotions to Imagine Success or Fear of Failure of 25.87, second Dare to Take Risks the average is 25.59, third Persevering and Working Hard the average value is 25.52 , the four Enthusiasm and Agile (Mobile) the average score is 25.37, the fifth Requires Feedback the average value is 25.37, the sixth is Personally Responsible for His Actions and Decisions the average value is 26.49, the Belief in Himself trait is obtained an average of 25.54, the eighth Have Broad Knowledge obtained an average of 25.22, the ninth Ability To Inspiring the average value of 24.47, the tenth Leadership Skills the average value of 25.03, the eleventh Innovators (Innovators) the average value of 25.54 and the twelfth Pursuit of Success the average value of 25.97. So it can be concluded that the entrepreneurial intention of each respondent is at a moderate level because it is in the range of values between 19-28.5.

Copyright (C) Ekuitas: Jurnal Pendidikan Ekonomi. All rights reserved.

\footnotetext{
* Corresponding author.

E-mail : reuniku09@gmail.com (Siti Reuni Inayati )
} 


\section{Pendahuluan}

Kewirausahaan (entrepreneurship) adalah suatu sikap mental yang dimiliki seseorang berupa kreativitas, aktif dan berdaya cipta yang bertujuan menciptakan hal unik serta baru agar berguna untuk orang banyak. Kegiatan enterpreneurship memainkan peran yang cukup penting dalam mendorong pembangunan ekonomi dan sosial. Apabila suatu negara mempunyai penduduk yang berjiwa enterpreneurship tinggi adalah hal yang bagus sebab bisa meningkatkan ekonomi suatu negara. Jiwa entrepreneurship itu sendiri ialah jiwa produktif yang berkemampuan menemukan opportunity serta mengkonversikannya menjadi suatu profit bisnis, maka dengan banyaknya bisnis yang dibangun bisa lebih mensejahterakan serta menurunkan angka pengangguran. Sehingga, untuk dapat mengembangkan perekonomian Indonesia dengan pesat, saat ini dibutuhkan adanya wirausaha muda di Indonesia karena melihat dari persentase wirausaha dan total penduduk yang masih sangat sedikit jumlahnya.

Menteri BUMN, mengatakan level entrepreneurship di Indonesia masih lebih kecil dibanding negara tetangga di Asia Tenggara. Dimana di Indonesia tingkat kewirausahaannya kisaran 3,47\% dari total penduduknya. Malaysia sudah berada kisaran $4,74 \%$ dan Thailand $4,26 \%$. Singapura menjadi urutan tertinggi yakni $8,76 \%$ penduduknya. Hal ini menyebabkan kawula muda Indonesia merupakan dasar dalam berwirausaha di masa yang akan datang dan juga perlu untuk semakin ditingkatkan (Merdeka.com, 2021). Perguruan tinggi dan Sekolah juga punya peranan penting dalam hal menghasilkan lulusan yang berkompeten yang diperlukan di bisnis serta memberi kemampuan berwiraswasta bagi lulusan supaya tidak cuma mencari kerja tapi juga berkemampuan menciptakan pekerjaan dan produk yang memiliki nilai serta kualitas tinggi.

Banyaknya lulusan yang menganggur merupakan permasalahan pokok yang dihadapi oleh perguruan tinggi. Biro Pusat Statistik pada Mei 2021 mencatat, angka pengangguran di Indonesia hampir 8,75 juta jiwa pada Februari 2021. Angka itu bertambah 26,26\% dibanding periode yang sama ditahun sebelumnya yakni mencapai 6,93 juta jiwa. Namun demikian, jumlah pengangguran itu turun $10,44 \%$ dari bulan Agustus 2020 yang angkanya 9,77 juta jiwa (Databoks, 2021). Pengangguran dan peningkatan perekonomian di Indonesia salah satunya dapat diatasi dengan cara lebih meningkatkan intensi berwirausaha generasi muda. Semakin banyak orang mempunyai jiwa wirausaha maka akan semakin banyak pula lahir pengusaha muda. Semakin banyaknya jumlah pengusaha maka semakin banyak tercipta lapangan kerja. Semakin banyak lapangan kerja, bisa mempermudah masyarakat memilih pekerjaan yang disenangi dan sesuai dengan keahlian yang dimiliki serta bisa memilah industri yang mampu memberi layanan serta kesejahteraan yang terbaik.

Perguruan Tinggi serta Sekolah berfungsi penting guna menghasilkan lulusan yang mempunyai kompetensi yang diperlukan di bisnis ataupun membagikan keahlian berwirausaha untuk alumni supaya tidak hanya mencari kerja namun juga sanggup menghasilkan pekerjaan, serta menghasilkan produk bernilai dan bermutu tinggi. Terbatasnya kesempatan kerja ialah kasus yang di hadapi tamatan sekolah tinggi atau universitas, hingga mengakibatkan pengangguran intelektual di Indonesia smakin meningkat (Adhimursandi, 2016).

Kemampuan kewiraan seseorang memiliki efek yang sangat besar bagi atensi berwirausaha, maka diperlukan suatu usaha guna meningkatkan kemampuan kewirausahaan mahasiswa. Kenaikan serta pengembangan kemampuan kewirausahaan mahasiswa bisa memberi kontribusi yang positif pada penerapan operasional serta keberhasilan wirausaha mahasiswa itu sendiri (Satrya, 2015). Riset (Inayati \& Ihwandi, 2020) menampilkan kalau kemampuan wirausaha Mahasiswa UGR terletak pada posisi menengah/sedang.

Jumlah wirausaha yang masih sedikit juga ada kaitannya dengan rendahnya intensi berwirausaha. Intensi berwirausaha ialah potensi seseorang untuk memberanikan dirinya didalam mencukupi kebutuhan hidupnya dan juga mengatasi problematika hidup. Intensi berwirausaha juga diartikan sebagai kecenderungan keinginan personal untuk bertindak sebagai wirausaha dengan menghasilkan produk baru melalui kesempatan bisnis dan pengambilan risiko. Semakin tinggi minat seseorang dalam berwirausaha semakin tinggi pula seseorang mempersiapkan diri untuk bisa lebih mandiri baik secara personal maupun financial. Hal tersebut berakibat berkurangnya angka pengangguran yang ada di Indonesia.

Riset tentang intensi berwirausaha sudah banyak dilakukan antara lain oleh (Yuniasanti \& Verasari, 2015) yang menunjukkan bahwa intensi berwirausaha mahasiswa tingkat akhir Mahasiswa di Yogyakarta rata-rata berada pada level sedang. Riset (Nugroho, 2015) memperoleh hasil bahwa karakteristik jiwa wirausaha mahasiswa UTM mayoritas cita-cita menjadi wirausaha sekitar $17 \%$ dan sisanya $83 \%$ cita-cita menjadi PNS, dosen dan lain-lain. Riset (Pranania \& Sanawiri, 2018) menunjukkan bahwa variable intensi wirausaha sebesar 5,04 yang mensinyalir bahwa mahasiswa Universitas Brawijaya siap berwirausaha setelah menyelesaikan kuliah di Universitas Brawijaya. Riset (Sobron et al., 2020) menunjukkan minat 
berwirausaha mahasiswa melalui hasil observasi, angket dan interview berada pada level sangat tinggi. Riset (Rahmadani, 2021) hasilnya menggambarkan intensi kewirausahaan mahasiswa yang tinggi pada perguruan tinggi negeri yang mempunyai badan hukum Kota Bandung menunjukkan hasil yang tinggiPenyebab tinggi rendahnya intensi berwirausaha bisa disebabkan oleh beberapa faktor. Riset (Yohana, 2016) menghasilkan pendidikan kewirausahaan serta motivasi berwirausaha mempengaruhi intensi berwirausaha. Riset (Hasmidyani et al., 2020) menunjukkan pendidikan kewirausahaan, lingkungan berwirausaha, norma subyektif, dan sikap berwirausaha mempengaruhi minat wirausaha. Demikian pula riset (Budiono \& Felya, 2020) yang menunjukkan sikap berpengaruh terhadap Minat Kewirausahaan Mahasiswa Fakultas Ekonomi Manajemen Universitas Tarumanagara. Motivasi berprestasi dan takut gagal mempengaruhi intensi kewirausahaan di kalangan mahasiswa (Farradinna \& Fikri, 2020). Pengetahuan kewirausahaan serta self efficacy mempengaruhi minat berwirausaha (Damayanti \& Hidayatulloh, 2020).

Riset ini bertujuan untuk mengetahui level intensi berwirausaha mahasiswa berdasarkan 12 ciriciri wirausaha yang dikemukakan oleh (D. Anggadiredja, 1991). Menurut (D. Anggadiredja, 1991), mencoba mengidentifikasikan ciri-ciri kepribadian seorang wiraswasta diantaranya adalah sebagai berikut yaitu Memiliki Emosi untuk Membayangkan Kesuksesan atau Takut gagal, Berani Menanggung Risiko, Gigih dan Pekerja Keras, Semangat dan Gesit (Mobile). Membutuhkan feedback, Bertanggungjawab Secara Personal atas sikap dan Keputusannya, Percaya pada Dirinya Sendiri, Mempunyai Pengetahuan Luas, Kemampuan Untuk Menghimbau, Kecakapan Memimpin, Pembaharu (Inovator), dan Memburu Kesuksesan.

Bersumber pada sebagian karakteristik di atas bisa diketahui jika ada banyak identitas yang dimiliki oleh seseorang wirausaha. Seseorang wirausaha wajib bisa mengidentifikasi kesempatan yang terdapat di sekitar lingkunganya dan menggunakan kesempatan tersebut guna dijadikan sesuatu usaha yang mempunyai nilai tambah. Sebagian ciri ataupun karakteristik diatas menunjukkan kalau wirausaha butuh kerja keras buat bisa jadi wirausaha berhasil yang kelak berguna bagi diri sendiri serta orang di lingkungannya. Keberhasilan wirausaha dengan kerja keras, cermat, dalam jangka panjang, hendak mempunyai sebagian arti secara pribadi yakni mendapatkan kontrol atas keterampilan diri, menggunakan kemampuan serta melaksanakan transformasi, mendapatkan faedah finansial tanpa batasan, berkontribusi kepada warga serta memperoleh pengakuan atas bisnisnya (Kusworo, 2018). Rye dalam (Saiman, 2015) juga menyimpulkan ciri berhasil untuk seseorang wirausahawan seperti mengendalikan diri, berusaha menyelesaikan urusan, memusatkan diri sendiri, pengelolaan dengan sasaran, menganalisis peluang, mengendalikan individu, berfikir kreatif, pemecah permasalahan, serta pemikir objektif. Tidak hanya kesuksesan, Rye pun merumuskan ciri kegagalan yang paling terlihat pada seseorang wirausaha semacam kurangnya pengalaman manajemen, perencanaan keuangan, posisi usaha yang tidak cocok, pengendalian bisnis, pembelanjaan yang sangat besar di dini, manajemen piutang, pengabdian serta memperluas usaha yang berlebih.

Seseorang wirausaha dengan bermacam inovasi serta kreativitas secara tak langsung pula akan menyebabkan berkurangnya total pengangguran penduduk dilingkungan bisnisnya. Riset ini ialah riset lanjutan dari riset (Inayati \& Ihwandi, 2020), dimana riset sebelumnya meneliti mengenai identifikasi potensi ciri-ciri wirausaha pada Mahasiswa UGR, sementara itu riset ini mencoba untuk mengetahui level intensi berwirausaha Mahasiswa UGR berdasarkan ciri (D. Anggadiredja, 1991). Dengan adanya riset ini diharapkan dengan meningkatnya potensi yang ada pada mahasiswa akan semakin meningkatkan minat kewirausahaan yang dimiliki oleh Mahasiswa Universitas Gunung Rinjani pada khususnya dan Masyarakat Indonesia umumnya.

\section{Metode}

Tipe riset yang dipakai dalam riset ini merupakan tipe riset kuantitatif yang analisis datanya dengan statistik deskriptif yaitu statistik yang digunakan untuk menganalisis informasi dengan teknik mendeskripsi ataupun mendeskripsikan informasi yang sudah dikumpulkan tanpa bermaksud membuat konklusi yang berguna secara universal ataupun general (Sugiyono, 2019). Periset memilah teknik riset tersebut ialah karena ada kaitannya dengan judul ataupun rumusan permasalahan yang sudah diungkap periset pada bagian awal, dimana riset ini hanyalah ingin mengenali tingkatan intensi berwirausaha Mahasiswa Universitas Gunung Rinjani dengan menggambarkan informasi sampel serta tidak mau membuat simpulan yang berlaku bagi populasi tempat pengambilan sampel. Untuk mengetahui tinggi rendahnya intensi berwirausaha pada mahasiswa peneliti menggunakan kategorisasi yang dibuat berdasarkan rerata hipotetik, dimana intensi rendah $<18.5$, intensi sedang antara 19-28.5, dan kategori tinggi $>29$. 
Riset ini dilakukan di Universitas Gunung Rinjani Kabupaten Lombok Timur Provinsi NTB. Waktu riset adalah bulan Februari sampai Agustus 2021. Populasi riset seluruh mahasiswa UGR angkatan 2017/2018 yang masih aktif dan sudah menempuh matakuliah kewirausahaan yang jumlahnya 241 orang. Sampel ditentukan dengan teknik simple random sampling dan besaran sampel ditentukan dengan rumus Slovin sehingga jumlah sampel diperoleh 150 orang mahasiswa yang dijadikan sebagai responden. Teknik pengumpulan data berupa angket yang dibagikan pada mahasiswa sebagai responden dan diminta mengisi serta menjawab (menanggapi).

\section{Hasil dan pembahasan}

Tabel berikut ini menyajikan tingkat intensi berwirausaha dari 150 orang responden berdasarkan 12 ciri wirausaha oleh Anggadiredja dan Djajamihardja.

Tabel 1 . Deskripsi Intensi Berwirausaha Mahasiswa Berdasarkan 12 Ciri Wirausaha Anggadiredja dan Djajamihardja

\begin{tabular}{cccccc}
\hline & $\begin{array}{c}\text { Jumlah } \\
\text { responden }\end{array}$ & Minimum & Maximum & Mean & $\begin{array}{c}\text { Tingkat intensi } \\
\text { berwirausaha }\end{array}$ \\
\hline Ciri_1 & 150 & 19 & 39 & 25.87 & Sedang \\
Ciri_2 & 150 & 16 & 36 & 25.59 & Sedang \\
Ciri_3 & 150 & 17 & 37 & 25.52 & Sedang \\
Ciri_4 & 150 & 19 & 40 & 25.37 & Sedang \\
Ciri_5 & 150 & 17 & 35 & 25.36 & Sedang \\
Ciri_6 & 150 & 18 & 36 & 26.48 & Sedang \\
Ciri_7 & 150 & 18 & 35 & 25.54 & Sedang \\
Ciri_8 & 150 & 15 & 78 & 25.22 & Sedang \\
Ciri_9 & 150 & 19 & 32 & 24.46 & Sedang \\
Ciri_10 & 150 & 18 & 33 & 25.02 & Sedang \\
Ciri_11 & 150 & 19 & 36 & 25.54 & Sedang \\
Ciri_12 & 150 & 17 & 37 & 25.97 & Sedang \\
\hline Keterangan
\end{tabular}

Keterangan :

$<18.5$ = level rendah, 19-28.5 = level sedang, $>29=$ level tinggi

1. Memiliki Emosi untuk Membayangkan Keberhasilan atau Takut Gagal

Seorang wirausaha perlu memiliki emosi didalam membayangkan keberhasilan tujuannya dan takut gagal mencapainya. Emosi ini nantinya menjadi faktor motivasi dalam pencapaian tujuan. Pada tabel bisa dilihat nilai mean nya adalah 25.87, sehingga termasuk dalam kategori atau level sedang.

2. Berani Menanggung Risiko

Kesuksesan selalu diinginkan oleh seorang wiraswasta. Kesuksesan ini diraih dengan cara menanggung risiko yang moderat, maksudnya yaitu risk seeker yang tak terlalu menantang namun juga tak terlalu mudah. Seorang wiraswasta selalu menginginkan suatu sukses, suka menantang usaha-usaha yaitu usaha-usaha yang memberikan kesempatan yang tidak terlalu sulit untuk berhasil atau gagal serta lebih bahagia dan senang dengan usaha-usaha yang orang lain takut untuk memasukinya. Berbeda dengan orang biasa, seorang wirausaha tidak sama sekali menghindari risiko, malah seakan-akan mencarinya karena risiko dinilai untuk mengingatkan tentang sumber-sumber yang dimilikinya. Pada tabel bisa dilihat nilai mean ciri kedua didapatkan 25.59, sehingga termasuk level sedang.

3. Gigih dan Bekerja Keras

Seorang wiraswasta akan mengejar tujuannya sejauh kemampuannya. Dia lari dibelakangnya, seolaholah nasibnya tergantung pada tujuan itu dan memperkuatnya dengan segala bakat, keterampilan, kemampuan dan perasaannya. Dia selalu bertahan, gigih dan bekerja keras walaupun menghadapi banyak hambatan. Dia tidak pernah merasa adanya tekanan yang begitu besar, karena dia tumbuh dengan subur apabila dibawah tekanan. Pada tabel diatas bisa dilihat nilai rata-rata ciri ketiga didapatkan sebesar 25.52, sehingga termasuk pada level intensi sedang.

4. Semangat dan Gesit (Mobile)

Seorang wiraswasta membuat dunia berputar atau hidup, karena begitu bersemangat sehingga sukar untuk menantangnya. Daya kerjanya cukup tinggi, karena dia bekerja rata-rata lebih dari 8 jam setiap hari, jauh lebih banyak dari kapasitas normal kebanyakan orang. Pada tabel bisa dilihat bahwa nilai rata-rata ciri keempat yang didapatkan sebesar 25.37, artinya berada pada level sedang. 


\section{Memerlukan Umpan Balik}

Seorang wiraswasta selalu ingin tahu sampai dimana keberhasilan usahanya, hingga dia sering dijuluki "pengejar penghargaan". Dia mencari umpan balik bukan hanya untuk memperoleh kesenangan saja, akan tetapi untuk lebih banyak kegiatan yang telah dikerjakannya. Pada tabel bisa dilihat nilai rata-rata ciri kelima didapatkan 25.36, sehingga berada pada level intensi sedang. Bertanggungjawab Secara Personal atas sikap dan Keputusannya.

Seorang wiraswasta ingin sekali dianggap bertanggungjawab atas pekerjaanya yang berhasil. Dia tidak dapat duduk dalam tim sebagai anggota yang bekerja keras, sedangkan orang lain mengambil semua kebanggaan yang dihasilkannya. Dia selalu ingin membuat roda berputar, sedangkan anggota lainnya mengikutinya. Dia selalu mencetuskan suatu pemikiran dan mengambil prakarsa. Dia percaya bahwa dia secara pribadi bertanggungjawab atas cara dan kelangsungan hidup usahanya. Pada tabel bisa dilihat nilai rata-rata ciri keenam 26.49 , artinya berada pada level intensi sedang.

6. Percaya pada Dirinya Sendiri

Seorang wiraswasta adalah orang yang penuh keberanian, keras, kuat, atau tangguh. Dia percaya pada kemampuannya untuk berhasil dan selalu memperlihatkannya. Dia mengalami kehidupan dengan penuh keyakinan. Apabila orang lain menganggap lingkungan yang hebat penuh ketakjuban, dia menggangggap lingkungannya sebagai sebagai suatu sarana yang dapat dimanfaatkan sebagai sebagai tujuan usahanya. Dia sanggup untuk terjun pada hal-hal yang masih asing untuknya. Oleh karena itu, sebagian orang beranggapan bahwa menyokong seorang wiraswasta terlalu banyak risikonya. Pada tabel bisa dilihat nilai rata-rata ciri ketujuh diperoleh 25.54 , sehingga termasuk dalam level intensi sedang.

7. Mempunyai Pengetahuan Luas

Para wiraswasta yang berhasil, banyak yang tidak tamat sekolah dari sekolah formal misalnya SMA apalagi perguruan tinggi, tetapi sebenarnya mereka penuh dengan pengetahuan yang luas dan biasanya ahli dalam pekerjaan atau produk yang dibuatnya. Seorang wiraswasta selalu belajar dengan baik mengenai pengetahuan tentang produk yang akan dihasilkannya, sehingga dia tidak hanya semata-mata tergantung pada seorang ahli yang dia pekerjakan pada perusahaannya. Dia tahu benar tentang apa, bagaimana, dimana, dan bilamana produk yang akan dihasilkan harus terjadi. Pada tabel bisa dilihat nilai mean ciri kedelapan diperoleh 25.22, sehingga termasuk dalam level intensi sedang.

8. Kemampuan Untuk Menghimbau

Seorang wiraswasta harus berbicara yang dapat menggairahkan orang lain. Sehingga dengan demikian, dia cenderung untuk dapat menguasai orang-orang disekitarnya dan mampu menghimbau. Pada tabel bisa dilihat nilai mean yang diperoleh ciri kesembilan sebesar 24.47, sehingga termasuk dalam level intensi sedang.

9. Kecakapan Memimpin

Seorang wiraswasta adalah seorang pemimpin. Dia selalu mengatur orang-orang agar mereka mau mengerjakan sesuatu untuknya. Walaupun pemilik perusahan, namun diapun mampu mendelegasikan beberapa wewenang dan tanggungjawabnya kepada orang yang dipekerjakannya. Pada tabel bisa dilihat bahwa nilai rata-rata ciri kesepuluh 25.03, sehingga termasuk dalam level intensi sedang.

10. Pembaharu (Inovator)

Seorang wiraswasta sangat kreatif untuk mencari cara baru dan lebih praktis untuk mengerjakan pekerjaannya. Dia selalu tidak puas dengan cara-cara yang telah ada, betapapun mudahnya cara-cara itu. Dia selalu mencoba meningkatkan cara-cara tersebut untuk menemukan yang paling mudah. Pada tabel bisa dilihat nilai rata-rata ciri kesebelas 25.54 sehingga termasuk level intensi sedang.

\section{Memburu Keberhasilan}

Seorang wiraswasta tidak hanya menaruh perhatian terhadap hasil akhir yang dicapainya sebagai suatu tujuan, tetapi dia menaruh perhatian pula pada proses bagaimana mencapai tujuan, seakanakan dia mengejarnya dengan penuh kegairahan. Dia menjalankannya demi kepuasan yang dia rasakan dalam mengejar pekerjaan yang hebat. Pada tabel bisa dilihat untuk nilai rata-rata ciri kedua belas sebesar 25.97, sehingga termasuk dalam level intensi sedang.

Berdasarkan perolehan angket secara menyeluruh didapatkan total rata- rata nilai 150 respondent berada di rentang antara 19- 28.5 yang berarti terletak pada kategori menengah/sedang.

\section{Simpulan dan saran}

Dari hasil olah data kuisioner 150 orang responden, maka dapat disimpulkan bahwa intensi berwirausaha masing-masing responden memiliki rentang nilai antara 19-28.5. sehingga berada pada kategori sedang. Pentingnya paham akan potensi diri dalam meningkatkan kemampuan diri menjadi 
seseorang wirausaha, maka perlu mengevaluasi terlebih dahulu siapa diri ini sebenarnya juga bagaimana penilaian orang lain terhadap kita. Penilaian terhadap diri seseorang, langkah awalnya adalah wajib memahami kekurangan yang ada dalam diri kemudian memperbaikinya, berikutnya melakukan identifikasi mengenai potensi apa yang dimiliki seseorang yang kemudian diganti menjadi sebuah kompetensi yang dilapisi dengan atitude/sikap yang baik, dengan demikian seseorang dapat menggapai kesuksesan yang diinginkan. Setelah mengenali potensi yang ada, maka dapat diketahui minat atau intensi seseorang terhadap wirausaha.

Potensi kewirausahaan yang dimiliki mahasiswa memiliki dampak paling besar terhadap intensi berwirausaha sehingga terlebih dahulu seseorang perlu mengetahui apakah siap ataukah belum untuk terjun ke suatu jenis bisnis dengan cara mengenal potensi diri sendiri atau orang lain. Model Anggadiredja dan Djajamihardja adalah salah satu model untuk mengetahui potensi ciri seorang wirausaha apa saja yang belum ada sehingga dapat diupayakan dan diperbaiki dan bisa mengetahui apakah individu tersebut siap ataukah belum dalam berbisnis. Hasil ini sejalan dengan riset yang dilakukan (Inayati \& Ihwandi, 2020) yang menunjukkan bahwa potensi ciri wirausaha yang dimiliki mahasiswa Universitas Gunung Rinjani yaitu berada pada kategori sedang, sehingga intensi berwirausaha yang dimiliki juga sedang. Sehubungan dengan hasil riset yang menunjukkan bahwa responden rata-rata memiliki intensi berwirausaha sedang, sehingga perlu dilakukan riset lanjutan tentang faktor-faktor apa saja yang mempengaruhi intensi mahasiswa untuk berwirausaha berdasarkan ciri wirausaha menurut (D. Anggadiredja, 1991)

\section{Daftar Rujukan}

Adhimursandi, D. (2016). FAKTOR-FAKTOR YANG MEMPENGARUHI NIAT KEWIRAUSAHAAN Doddy Adhimursandi Fakultas Ekonomi dan Bisnis Universitas Mulawarman, Indonesia. Jurnal Ekonomi Dan Manajemen, 13(1), 193-210.

Budiono, H., \& Felya. (2020). Pengaruh Theory Of Planned Behavior Terhadap Minat Kewirausahaan Mahasiswa Universitas Tarumanagara. Jurnal Manajerial Dan Kewirausahaan, II(1), 131-140.

D. Anggadiredja, D. dan D. (1991). Ciri-ciri Kewiraswastaan. Lembaga Pengembangan Perbankan Indonesia.

Damayanti, V., \& Hidayatulloh, A. (2020). Anteseden Self Efficacy dan Dampaknya pada Minat Berwirausaha. Owner (Riset Dan Jurnal Akuntansi), 4(2), 433. https://doi.org/10.33395/owner.v4i2.254

Databoks. (2021). Jumlah Pengangguran Capai 8,75 Juta Orang per Februari 2021. https://databoks.katadata.co.id/datapublish/2021/05/05/jumlah-pengangguran-capai-875-jutaorang-per-februari-2021

Farradinna, S., \& Fikri, F. (2020). Intensi Kewirausahaan Dikalangan Mahasiswa Ditinjau dari Motivasi Berprestasi dan Ketakutan pada Kegagalan. Jurnal Ekonomi Bisnis Dan Kewirausahaan, 9(3), 177. https://doi.org/10.26418/jebik.v9i3.39523

Hasmidyani, D., Soetjipto, B. E., Wahjoedi, W., \& ... (2020). Model Intensi Berwirausaha Di Perguruan Tinggi (Studi Pada Mahasiswa Universitas Sriwijaya, Palembang). Repository Unsri. https://repository.unsri.ac.id/31137/

Inayati, S. R., \& Ihwandi, L. R. (2020). Identifikasi Potensi Ciri-ciri Wirausaha Dengan Model Anggadiredja dan Djajamihardja Pada Mahasiswa Universitas Gunung Rinjani. JPEK (Jurnal Pendidikan Ekonomi Dan Kewirausahaan), 4(2), 207-216. https://doi.org/10.29408/jpek.v4i2.2733

Kusworo, dan I. P. (2018). ANALISIS PARADIGMA MAHASISWA TERHADAP KEWIRAUSAHAAN (STUDI PADA MAHASISWA PROGRAM STUDI MANAJEMEN UNIVERSITAS PAMULANG TAHUN AJARAN 2017/2018). Pendidikan, Hukum, Dan Bisnis, 2, 227-249. https://doi.org/10.32493/eduka.v3i2.3810

Merdeka.com. (2021). Jumlah Wirausaha Indonesia Jauh di Bawah Malaysia dan Thailand. https://www.merdeka.com/uang/jumlah-wirausaha-indonesia-jauh-di-bawah-malaysia-danthailand.html

Nugroho, A. A. V. dan T. R. D. A. (2015). Intensi Kewirausahaan Mahasiswa Universitas Trunojoyo Madura. Agriekonomika, 4, 107-119.

Pranania, I. D., \& Sanawiri, B. (2018). Intensi Berwirausaha Mahasiswa Brawijaya. Jurnal Administrasi Bisnis (JAB)/Vol, 55(1).

Rahmadani, R. (2021). Intensi Kewirausahaan Mahasiswa Perguruan Tinggi Negeri Di Kota Bandung. Jurnal Neraca: Jurnal Pendidikan Dan Ilmu Ekonomi Akuntansi, 5(1), 32. https://doi.org/10.31851/neraca.v5i1.5474

Saiman, L. (2015). Kewirausahaan: Teori, Praktik, dan Kasus-kasus. Salemba Empat.

Satrya, I. B. H. dan I. G. M. S. (2015). Potensi Kewirausahaan Mahasiswa di Fakultas Ekonomi dan Bisnis 
Universitas Udayana. E-Jurnal Manajemen Unud, 4, 4559-4594.

Sobron, A. N., Titik, S., \& Meidawati, S. (2020). Jurnal Inovasi Penelitian. Jurnal Inovasi Penelitian, 1(3), 1-4. Sugiyono. (2019). Metode Penelitian Kuantitatif, Kualitatif, dan R\&D (Kedua). Alfabeta.

Yohana, C. (2016). Faktor-Faktor yang Mempengaruhi Intensi Berwirausaha pada Mahasiswa Universitas di Jakarta. 2(1), 1-23. http://pub.unj.ac.id/index.php/jbmk/article/view/236/201

Yuniasanti, R., \& Verasari, M. (2015). Intensi Berwirausaha Pada Mahasiswa Tingkat Akhir. In Psikologika (Vol. 20, Issue 1, pp. 91-99). 